\title{
PERBEDAAN HASIL BELAJAR IPA (BIOLOGI) SISWA PADA PENERAPAN MODEL PEMBELAJARAN KOOPERATIF TIPE TEAM GAMES TOURNAMENT (TGT) DENGAN TIPE NUMBERED HEAD TOGETHER (NHT)
}

\section{THE DIFFERENTIATION BETWEEN THE STUDENT ACHIEVEMENT SCIENCE BIOLOGY USING COOPERATIVE LEARNING TYPE TEAM GAMES TOURNAMENT (TGT) WITH NUMBERED HEADS TOGETHER (NHT)}

\author{
Nurayani, K Khairuddin dan Ahmad Raksun \\ Program Studi Pendidikan Biologi FKIP Universitas Mataram, Mataram, Indonesia \\ Email: khairuddin.fkip@unram.ac.id
}

Diterima: 18 Agustus 2020. Disetujui: 26 Agustus 2020. Dipublikasikan: 30 September 2020

\begin{abstract}
Abstrak: Penelitian ini bertujuan untuk mengetahui perbedaan hasil belajar IPA Biologi Siswa pada Penerapan model pembelajaran kooperatif tipe TGT dengan NHT di kelas VII MTsN 2 Mataram Tahun Ajaran 2015/2016. Populasi dalam penelitian ini adalah semua siswa kelas VII MTsN 2 Mataram berjumlah enam kelas dengan jumlah siswa 226 orang. Sampel diperoleh dengan teknik purposive sampling sehingga diperoleh kelas VII C sebagai eksperimen 1 dan VII D sebagai kelas eksperimen 2. Kelas VII C menggunakan model pembelajaran kooperatif tipe TGT, sedangkan kelas VII D menggunakan model pembelajaran kooperatif tipe NHT. Perolehan data dengan menggunakan tes untuk melihat hasil belajar aspek kognitif dan lembar observasi untuk mengetahui aktifitas siswa dan keterlaksanaan RPP. Pengujian hipotesis menggunakan uji t polled varian karena data terdistribusi normal dan bersifat homogen. Hasil Post-test $t_{\text {hitung }}=5.28$ dan harga Kritik tabel $=2.02$ sehingga hasil uji hipotesis yang diperoleh menyatakan Ho ditolak dan Ha diterima sehingga terdapat perbedaan hasil belajar IPA Biologi siswa antara yang menggunakan model TGT dengan NHT. Hasil belajar ranah kognitif menggunakan model pembelajaran kooperatif tipe TGT lebih tinggi daripada model pembelajaran kooperatif tipe NHT.
\end{abstract}

Kata Kunci: Model Pembelajaran Kooperatif, Team Games Tournament, Numbered Head Together, Hasil Belajar.

\begin{abstract}
This research aims was to find out the differentiation between the student achievement science Biology taught using cooperative learning types TGT with NHT at the seventh grade of MTsN 2 Mataram in academic year 2015/2016. The population of the research were all of 226 students of grade seventh of MTsN 2 Mataram that consists of six classes. The sample were Class VII C as the first experimental class and class VII $\mathrm{D}$ as the second experimental class. The samples were determine using purposive sampling technique. The first experiment class was taught using TGT and the second taught using NHT. Data of the research were collected using test for cognitive aspect and observation sheet for students activity and lesson plan implementation. The data were analyzed using $\mathrm{t}$ polled variance test because the data were normally distributed and homogeneous. The result of post-test showed $t_{\text {count }}=5.28$ and the value of critical $t_{\text {table }}=2.02$, it is indicate the result of hypothesis explained the Ho were denied and Ha were accepted, it means that there is a significant different between students learning achievement in learning science Biology taught using TGT model and NHT model.
\end{abstract}

Keywords: Cooperative Learning, Team Games Tournament, Numbered Head Together, and The Result of Learning.

\section{PENDAHULUAN}

Pendidikan merupakan proses mengubah tingkah laku siswa menjadi manusia dewasa yang mampu hidup mandiri dan sebagai anggota masyarakat dalam lingkungan alam sekitar. Pendidikan dijadikan tolak ukur seseorang mengenai cara berpikirnya, guna meningkatkan kesejahteraan dan mempertahankan hidup untuk menghadapi arus globalisasi. Disinilah peranan pendidikan memberi suatu konsep cara belajar yang efektif bagi peserta didik.

Sekolah merupakan lembaga pendidikan formal memiliki kewajiban meningkatkan kualitas sumber daya manusia (SDM) melalui berbagai cara seperti peningkatan mutu pendidikan. Salah satu, diantaranya adalah dengan memperbaiki teknik pembelajaran. Roestiyah [1] menjelaskan bahwa di dalam kegiatan pembelajaran, guru harus mengunakan model pembelajaran yang bervariasi seperti problem base learning (PBL), project base learning (PBL) [2] dan model yang lain agar siswa dapat belajar secara efektif dan efisien serta mengena pada tujuan yang diharapkan.

Penggunaan model pembelajaran penting dalam menunjang keberhasilan belajar siswa, sehingga penerapannya dalam pembelajaran di kelas dapat bermanfaat. Menurut Isjoni [3], model pembelajaran mengacu pada pendekatan yang akan 
digunakan, termasuk di dalamnya tujuan-tujuan pembelajaran, tahap-tahap dalam kegiatan pembelajaran dan pengelolaan kelas. Model pembelajaran dapat didefinisikan sebagai kerangka konseptual yang melukiskan prosedur sistematis dalam mengorganisasikan pengalaman belajar untuk mencapai tujuan belajar. Karp dan Yoels (2002) yang dikutip oleh Isjoni [4] menyatakan bahwa model pembelajaran yang paling sering dilakukan untuk mengaktifkan siswa adalah model pembelajaran kooperatif. Model pembelajaran kooperatif adalah salah satu model pembelajaran yang dapat meningkatkan aktifitas siswa, meningkatkan interaksi, meningkatkan penguasaan siswa terhadap materi pembelajaran, dan akan meningkatkan motivasi siswa untuk aktif dalam proses pembelajaran [2], termasuk untuk materi tentang klasifikasi makhluk hidup dan juga pengetahuan ekologi untuk pengelolaan ekoturisme [5], lingkungan [6], bioindikator [7], sistem hidroponik [8], dan zat gizi [9].

Menurut Johnson \& Johnson (1991) dalam Jufri [10], pembelajaran kooperatif memiliki dampak yang positif untuk siswa yang hasil belajarnya rendah sehingga mampu memberikan peningkatan hasil belajar yang signifikan. Keuntungan dari model pembelajaran kooperatif, antara lain: 1) memberikan dorongan kepada peserta didik untuk lebih bertanggung jawab terhadap proses belajarnya dan berusaha lebih kuat untuk berprestasi, 2) mengembangkan keterampilan berpikir kritis, 3) membentuk hububngan positif dengan teman sekelompok maupun peserta didik dari kelompok yang lain. Banyak ahli berpendapat bahwa model pembelajaran kooperatif unggul dalam membantu siswa memahami konsep-konsep sulit.

Banyak model pembelajaran kooperatif yang dapat digunakan. Dua diantaranya adalah model pembelajaran kooperatif TGT dan NHT. Model pembelajaran kooperatif dengan tipe TGT dan NHT sama-sama memiliki kelebihan sebagai model pembelajaran yang mengedepankan sikap toleransi, saling bergantung dan musyawarah dengan anggota kelompok dalam menjawab setiap pertanyaan yang diajukan guru. Kondisi peserta didik, sarana dan prasarana yang ada di MTsN 2 Mataram mendukung dilaksanakannya pembelajaran dengan model kooperatif tipe TGT dan NHT.

Hasil penelitan yang dilakukan oleh [11] menyimpulkan bahwa hasil belajar peserta didik pada materi operasi bentuk aljabar terdapat perbedaan setelah menggunakan model pembelajaran kooperatif tipe TGT dan NHT. Hasil belajar setelah diberikan tes menunjukkan adanya peningkatan dilihat dari perbandingan nilai pre test dan post test. Hasil belajar menggunakan TGT dan NHT sama-sama meningkat akan tetapi nilai ratarata kelas yang menggunakan model kooperatif tipe TGT lebih tinggi daripada kelas yang menggunakan model kooperatif tipe NHT.

Dari uraian di atas, kedua model pembelajaran kooperatif tersebut memiliki keunggulan masingmasing. Untuk mengetahui pendekatan yang lebih efektif dari kedua model pembelajaran kooperatif tersebut maka penelitian tentang "Perbedaan Hasil Belajar IPA (Biologi) Siswa pada Penerapan Model Pembelajaran Kooperatif Tipe Team Games Tournament (TGT) dengan Tipe Numbered Head Together (NHT) di Kelas VII MTsN 2 Mataram Tahun Ajaran 2015/2016" perlu dilakukan.

\section{METODE PENELITIAN}

Jenis penelitian ini adalah pre eksperimental. Penelitian ini dilakukan di MTsN 2 Mataram pada siswa kelas VII semester ganjil tahun ajaran 2015/2016. Populasi dari penelitian ini adalah seluruh kelas VII yang terbagi menjadi enam kelas, sampel penelitian diambil dengan menggunakan purposive sampling dan diperoleh kelas VIII C sebagai kelas eksperimen 1 dan kelas VII D sebagai kelas eksperimen 2. Kelas VII C menggunakan model pembelajaran kooperatif tipe TGT, sedangkan kelas VII D menggunakan model pembelajaran kooperatif tipe NHT. Materi yang dipelajari tentang klasifikasi makhluk hidup.

Variabel bebas dalam penelitian ini adalah pembelajaran kooperatif tipe TGT (Team Games Tournament) dan tipe NHT (Numbered Head Together). Sedangkan variabel terikat dalam penelitian ini adalah hasil belajar IPA Biologi siswa. Instrumen yang digunakan untuk mengukur hasil belajar aspek kognitif dengan menggunakan soal berupa pilihan ganda yang sudah valid dan reliabel sebanyak 35 soal. Analisis uji hipotesis menggunakan uji-t dengan bantuan program Microsoft Excel 2010.

\section{HASIL DAN PEMBAHASAN}

Nilai rata-rata post-test hasil belajar aspek kognitif siswa pada kelas TGT sebesar 72,78. Kelas NHT memiliki nilai rata-rata sebesar 61,87 . Perbandingan nilai rata-rata post-test yang diperoleh di kedua kelas sampel terlihat pada gambar 1 .

Uji perbedaan post-test dianalisis menggunakan rumus $t$-test pada program Microsoft Excel 2010. Secara singkat, analisis data post-test dapat dilihat pada Tabel 1 . 
Perbedaan nilai rata-rata post test

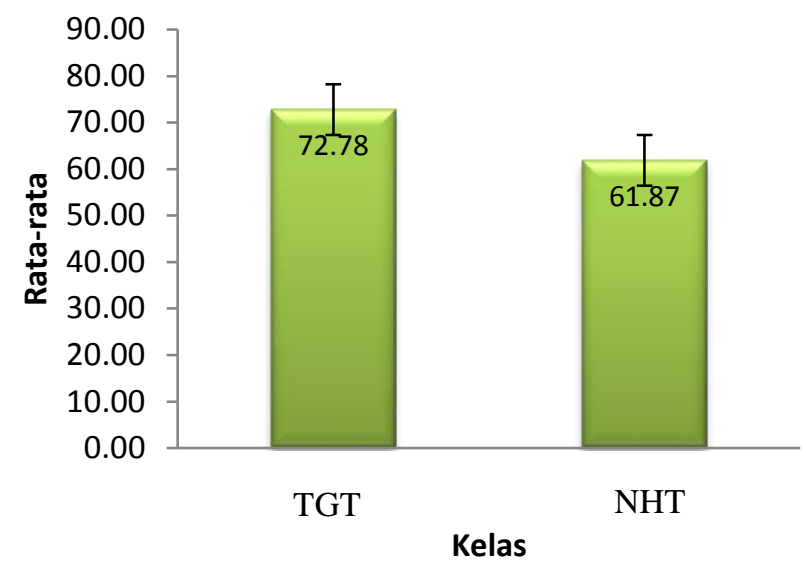

Gambar 1. Diagram batang rata-rata nilai Post test kelas TGT dan kelas NHT

Tabel 1. Hasil Uji Hipotesis Data Post-test Kelas TGT dan Kelas NHT

\begin{tabular}{llll}
\hline No & Statistik & Kelas TGT & Kelas NHT \\
\hline 1 & Jumlah sampel & 40 & 40 \\
2 & Rata-rata & 72.78 & 61.87 \\
3 & Varians $\left(\mathrm{S}^{2}\right)$ & 92.08 & 78.92 \\
4 & $\mathrm{t}_{\text {hitung }}$ & 5.28 & $\mathrm{t}_{\text {hitung }}>\mathrm{t}_{\text {tabel }}$ \\
5 & $\mathrm{t}_{\text {tabel }}$ & 2.02 & $\mathrm{H}_{0}$ ditolak, $\mathrm{H}_{\mathrm{a}}$ diterima \\
\hline
\end{tabular}

Berdasarkan analisis uji perbedaan hasil belajar aspek kognitif pada post-test menggunakan rumus (uji-t) pada program Microsoft Excel 2010, diketahui harga $t_{\text {hitung }}=5,28$ dengan derajat bebas 78 dan $\alpha=5 \%$ sehingga harga $t_{\text {tabel }}=2.02$. Berdasarkan hasil tersebut, diketahui $t_{\text {hitung }}$ lebih besar daripada $\mathrm{t}_{\text {tabel }}(5.28>2.02)$, sehingga Ho ditolak dan $\mathrm{Ha}$ diterima. Dengan demikian terbukti secara statistik bahwa terdapat perbedaan hasil belajar aspek kognitif antara siswa yang diberikan pembelajaran dengan model pembelajaran kooperatif tipe TGT dengan NHT.

Hasil yang diperoleh nilai rata-rata kelas TGT lebih tinggi dibandingkan dengan nilai rata-rata kelas NHT artinya bahwa model pembelajaran kooperatif tipe TGT memberikan hasil yang lebih baik pada materi klasifikasi makhluk hidup. Hal ini karena pada model pembelajaran TGT melibatkan peran siswa sebagai tutor sebaya, mengandung unsur permainan yang bisa menggairahkan semangat belajar dan mengandung reinforcement (penguatan). Siswa dikelompokkan dalam jumlah yang banyak sehingga semakin banyak ide yang akan diperoleh dan kelompok diskusi yang banyak dapat membantu dalam mempertimbangkan jawaban pada saat turnamen berlangsung. Siswa pada kelas TGT lebih aktif dalam mengikuti proses belajar mengajar jika dibandingkan dengan kelas NHT, baik dalam bertanya maupun mengemukakan pendapat. Model pembelajaran yang digunakan juga mempengaruhi aktivitas belajar siswa. Kelas yang menggunakan model TGT sangat antusias dalam mengikuti proses belajar mengajar karena adanya permainan. Sistem turnamen dan penilaian kelompok membuat siswa lebih tertarik dan tertantang.

Penelitian serupa juga dilakukan oleh Rahmawan [12] menyatakan bahwa hasil belajar aspek kognitif materi dasar-dasar kelistrikan lebih tinggi menggunakan model TGT dibandingkan dengan menggunakan model NHT. Hal ini karena penggunaan model TGT memberikan kesempatan kepada siswa untuk bertukar pikiran semakin banyak anggota dalam kelompok maka semakin banyak ide-ide yang diperoleh namun setiap anggota dari masing-masing kelompok tetap bersaing dalam melakukan permainan yang dapat merangsang kecerdasan dan kejujuran siswa. Pelaksanaan model NHT hanya melibatkan beberapa dari anggota kelompok. Jumlah anggota kelompok yang banyak menyebabkan tidak semua anggota kelompok mendapat giliran untuk presentasi. Berbeda dengan model TGT, setiap anggota kelompok mengikuti permainan yang menyenangkan dan mengikuti turnamen yang ditanyakan oleh guru sehingga dapat menumbuhkan persaingan yang sehat antar siswa, umumnya kesempatan presentasi hasil kerja untuk setiap kelompok sama. Hasil tersebut juga didukung hasil penelitian yang dilakukan oleh Wardani [13] pada materi kewarganegaraan, hasilnya 
menunjukkan bahwa kelas yang menggunakan model pembelajaran TGT memperoleh nilai ratarata yang lebih tinggi dibandingkan dengan kelas yang menggunakan model NHT. Hal ini karena pembelajaran dengan model TGT memberikan peluang untuk lebih banyak ide yang diperoleh dan dapat mempertimbangkan jawaban, sedangkan pada model NHT ide yang diperoleh sedikit, sulit untuk mempertimbangkan jawaban. Model pembelajaran NHT memiliki kelemahan, umumnya siswa yang pandai akan cenderung mendominasi sehingga dapat menimbulkan sikap minder dan pasif dari siswa yang lemah, siswa yang akatif makin meningkat pemahamannya [14]

Model pembelajaran TGT dan NHT memiliki pengaruh terhadap hasil belajar siswa menurut hasil penelitian yang dilakukkan oleh Sholihah [15]. Model pembelajaran TGT memperoleh hasil yang lebih baik dibandingkan dengan NHT. Penerapan kedua model tidak berpengaruh pada hasil belajar aspek afektif dan psikomotorik. Karena aspek afektif lebih dipengaruhi oleh faktor internal, sedangan model pembelajaran merupakan faktor luar. Hal serupa juga diperoleh Wulandari [16] yang menyatakan bahwa model pembelajaran kooperatif tipe TGT dan NHT mempengaruhi hasil belajar siswa, akan tetapi hasil belajar yang menggunakan model TGT lebih baik dibandingkan dengan model pembelajaran NHT. Hal ini dikarenakan pada model TGT siswa belajar lebih rileks disamping menumbuhkan tanggung jawab dan kerjasama untuk mencari, mengolah informasi seperti pelestarian lingkungan [17], bioindikator makroinvertebrata [ 18], [19], dan melaporkan melalui kegiatan presentasi dengan bimbingan guru [20]. Siswa terlibat lebih aktif karena siswa dapat mengungkapkan ide dan gagasan secara verbal dan dapat membandingkan ide-ide dengan orang lain.

Hasil uji hipotesis pada post-test terdapat perbedaan hasil belajar siswa antara yang menggunakan model pembelajaran kooperatif TGT dengan NHT. Kelas yang menggunakan model pembelajaran kooperatif tipe TGT adalah kelas eksperimen 1, dan kelas yang menggunakan model pembelajaran kooperatif tipe NHT adalah kelas eksperimen 2. Jadi pada kedua perlakuan kelas TGT memperoleh hasil yang lebih baik dibandingkan dengan kelas NHT. Hal ini terjadi karena pada proses pembelajaran berlangsung, kelas TGT lebih aktif jika dibandingkan dengan kelas NHT.

\section{KESIMPULAN}

Berdasarkan hasil penelitian dan pembahasan, maka kesimpulan yang diperoleh dalam penelitian ini adalah terdapat perbedaan hasil belajar IPA Biologi antara model pembelajaran kooperatif tipe TGT (Team Games Tournament) dengan NHT (Nmbered Heads Together) pada siswa kelas VII materi klasifikasi makhluk hidup di MTsN 2 Mataram tahun ajaran 2015/2016. Hasil belajar ranah kognitif menggunakan model pembelajaran kooperatif tipe TGT lebih tinggi daripada model pembelajaran kooperatif tipe NHT.

\section{DAFTAR PUSTAKA}

[1] Roestiyah, N. K. (2008). Strategi Belajar Mengajar. Jakarta: Rineka Cipta.

[2] Rha'ifa, F.A, Khairuddin, K, dan Merta, I.W. (2019). Perbedaan Hasil Belajar IPA Biologi Menggunakan Model Reciprocal Learning dan Model Problem Based Learning. Jurnal Pijar MIPA, Vol. 14 No.1, Maret 2019: [107-112]

[3] Isjoni, (2009). Pembelajaran Kooperatif: Meningkatkan Kecerdasan Komunikasi antar Peserta Didik. Yogyakarta: Pustaka Pelajar

[4] Isjoni. (2007). Cooperative Learning. Bandung: Alfabeta.

[5] Khairuddin, K dan Yamin, M. (2019). Megapodius reinwardt conservation based on ecological knowledge of local people to support sustainable ecotourism on Moyo Island. AIP Conference Proceedings 2199, 050004 (2019)

[6] Syukur, A, Khairudin, $\mathrm{K}$ dan Yamin, M. (2019). Budidaya Ramah Lingkungan Sebagai Strategi Pengentasan Kemiskinan Nelayan Skala Kecil Di Desa Ketapang Raya Lombok Timur. Jurnal Pengabdian Magister Pendidikan IPA 2019, (1) 2

[7] Khairuddin, K, Yamin, M, dan Syukur, A. (2019). Pelatihan Tentang Penggunaan Ikan Sebagai Indikator dalam Menentukan Kualitas Air Sungai di Ampenan Tengah Mataram. Jurnal Pengabdian Magister Pendidikan IPA 2019, (1) 2

[8] Ilhamdi, M. L., Khairuddin, K., Zubair, M. (2020). Pelatihan Penggunaan Pupuk Organik Cair (POC) Sebagai Alternatif Pengganti Larutan Nutrisi AB Mix pada Pertanian Sistem Hidroponik di BON Farm Narmada. Jurnal Pengabdian Masyarakat Sains Indonesia (JPMSI). 2(1): [40-44].

[9] Kusmiyati, Merta, I. W, Handayani, B.S, Khairuddin, K, dan Ilhamdi, M. L. (2019). Meningkatkan Pengetahuan Tentang Gizi Melalui"'Ayo Lengkapi Piringmu Dengan Makanan Bergizi" Pada Siswa SDN I Sesela. Jurnal Pendidikan dan Pengabdian Masyarakat. Vol. 2 No. 3 ,

[10] Jufri, A. W. (2010). Belajar dan Pembelajaran Sains. Lombok Barat NTB: Arga Puji Press.

[11] Margono, A, Budiyono, dan Imam, S. 2014. Eksperimentasi Model Pembelajaran Kooperatif Tipe Team Games Tournament dan Numbered Head Together Ditinjau dari Kecerdasan Emosional Siswa. Jurnal Elektronik Pendidikan Matematika. Vol. 2 (2)

[12] Rahmawan, A. D. (2013). Perbandingan Hasil Belajar Menerapkan Dasar-Dasar Kelistrikan Menggunakan Model Pembelajaran Kooperatif tipe TGT dengan Kooperatif Tipe NHT di 
SMKN 3 Jombang. Jurnal Pendidikan Teknik Elektro. Vol. 2 (2). Tahun 2013.

[13] Wardani, E. (2012). Perbedaan Penerapan Model Numbered Heads Together (NHT) dan Team Games Tournament (TGT) terhadap Proses dan Hasil Belajar Pendidikan Kewarganegaraan Siswa Kelas V SDN Bareng 3 Kota Malang. Skripsi. Malang: FIP

[14] Febrianti, Y, Khairuddin, K, dan M. Yamin. (2019). Perbedaan Hasil Belajar Siswa pada Penggunaan Model Pembelajaran Problem Based Learning dengan Model Pembelajaran Guided Discovery Learning pada Mata Pelajaran IPA Terpadu di SMPN 13 Mataram Tahun Ajaran 2016/2017. Jurnal Pijar MIPA(14) 2

[15] Shoolihah, A. (2012). Perbandingan Metode Pembelajaran Teams Games Tournament dan Metode Numbered Head Together dalam Meningkatkan Hasil Belajar Siswa. Jurnal Pendidikan Ekonomi. Vol. 1 (2).

[16] Wulandari, A. (2013). Perbandingan Hasil Belajar Kooperatif Tipe TGT dengan NHT
Terhadap Hasil Belajar Siswa. Skripsi. Bandar Lampung: Pendidikan Ekonomi.

[17] Khairuddin, K, Yamin, M, Syukur, A dan Kusmiyati, (2019). Penyuluhan tentang Upaya Pelestarian Lingkungan Hidup pada Siswa SMPN 3 Palibelo Kabupaten Bima. Jurnal Pendidikan dan Pengabdian Masyarakat. Vol. 2 No. 2:

[18] Khairuddin, K, Yamin, M, Syukur, A. (2016). Analisis kualitas kali Ancar dengan menggunakan bioindikator makro invertebrate. Jurnal Biologi Tropis. Vol 16 (2)

[19] Khairuddin, K, Yamin, M dan Syukur, A. 2018. Analisis Kandungnan Logam Berat pada Tumbuhan Mangrove Sebagai Bioindikator di Teluk Bima. Jurnal Biologi Tropis, JANUARIJUNI 2018: Volume 18 (1)

[20] Yamin, M, Jamaluddin, Syukur, A dan Khairuddin, K. (2019). Meningkatkan Kemapuan Guru Menerapkan Kurikulum Berbasis Komptensi Di Pondok Pesantren AlAziziah Gunungsari Lombok Barat. Jurnal Pengabdian Magister Pendidikan IPA 2019, (1) 2. 